\title{
A possible anti-inflammatory mechanism of ethyl acetate extracts of Teucrium stocksianum Bioss
}

Syed Muhammad Mukarram Shah

\begin{abstract}
Background: Teucrium stocksianum (T. stocksianum) is one of the important members of the genus Teucrium which contains numerous biologically active compounds. Traditionally, it is used for the treatment of fever, pain, as expectorant and blood purifier. Researchers are trying to discover plants origin, novel and safe remedies for the management of various ailments. The present study was aimed to determine the possible anti-inflammatory mechanism of ethyl acetate extract of T. stocksianum.

Methods: Preliminary, the ethanolic extract and sub-fractions were screened for anti-inflammatory potential at doses of 100, 200 and 300 mg/kg (i.p) body weight, using carrageenan induced paw edema test in mice. In-order to determine the possible mechanism of anti-inflammatory effect, the ethyl acetate fraction was ascertained with different phlogistic agents like histamine, bradykinin, prostaglandins $E_{2}$ and arachedonic acid via paw edema test in mice.

Results: The ethanolic extract and sub-fractions of T. stocksianum displayed marked to moderate anti-inflammatory activity in a carrageenan induced paw edema test in mice. Among the sub-fractions, ethyl acetate fraction (EAF) demonstrated excellent (66\%) anti-inflammatory action at the highest tested dose $(300 \mathrm{mg} / \mathrm{kg})$ that reached to the maximum value at $3^{\text {rd }}$ hour after carrageenan injection and remained significant (*** $\left.P<0.001\right)$ till $5^{\text {th }}$ hour of test sample administration. EAF revealed moderate effect against the paw edema induced by histamine (31.048 \%) while non-significant results (18.148 \%) were observed against the edema induced by bradykinin. The extract demonstrated significant (66.23-73.076 \%) anti-inflammatory potential against the edematogenic effect of prostaglandin $\mathrm{E}_{2}$. Moreover, the extract also significantly inhibited (51.33\%) the paw edema induced by arachedonic acid.

Conclusion: Our results suggest that the EAF has dual action and produced the anti-inflammatory effect by blocking both pathways of arachedonic acid metabolites (cyclooxygenase and lipoxygenase). Thus validating the traditional use of $T$. stocksianum and could provide a source of novel, effective and safe drug for the treatment of inflammation.
\end{abstract}

Keywords: Teucrium stocksianum, Anti-inflammatory mechanism, Histamine, Bradykinin, Arachedonic acid

\section{Background}

In the plant kingdom nature has bestowed the remedies of ailments. According to WHO, approximately 70-80 \% population of developing countries acquire their primary pharmaceutical care from medicinal plants [1]. Medicinal plants have diversified pharmacological potentials due to the presence of various classis of phytochemicals [2].

Lamiaceae is a famous cosmopolitan family comprising of about 200 genera and more than 4000 species disseminated all over the world particularly in the Mediterranean and mountainous region [3]. Phytochemicals evaluation of

Correspondence: shahpharmacist@yahoo.com

Department of Pharmacy, University of Malakand, Chakdara, Dir, Pakistan the family Lamiaceae revealed the presence of different classes of secondary metabolites. The most common compounds among the species are terpenoids, iridoids, phenolics compounds and flavonoids [4, 5]. T. stocksianum Boiss is a key member of the Lamiaceae family. It is used in folk medicine for the treatment of fever, sore throat, as expectorant, diabetes, foot burning sensation, body coolant and blood purifier [6,7]. In our previous work we extracted the essential oils from $T$. stocksianum which showed excellent analgesic activity [8]. The methanolic extract, sub-fractions and crud saponins of $T$. stocksianum exhibited marked antioxidant, analgesic, cytotoxic, phytotoxic and insecticidal activities [9-11]. It has been 
Table 1 Concentration dependent anti-inflammatory effect of ethyl acetate fraction of T.stocksianum (TSEAF) in carrageenan induced paw edema test

\begin{tabular}{lllllll}
\hline Sample/drug & Dose $\mathrm{mg} / \mathrm{kg}$ & $1 \mathrm{~h}$ & $2 \mathrm{~h}$ & $3 \mathrm{~h}$ & $4 \mathrm{~h}$ & $5 \mathrm{~h}$ \\
\hline DMSO $10 \%$ & $10 \mathrm{ml}$ & $0.220 \pm 0.109$ & $0.233 \pm 0.08$ & $0.235 \pm 0.08$ & $0.236 \pm 0.03$ & $0.236 \pm 0.02$ \\
EAF & 100 & $0.193 \pm 0.076$ & $0.173 \pm 0.061$ & $0.158^{*} \pm 0.05$ & $0.163^{*} \pm 0.09$ & $0.181 \pm 0.104$ \\
& 200 & $0.160^{*} \pm 0.051$ & $0.13^{* * *} \pm 0.051$ & $0.116^{* * *} \pm 0.05$ & $0.130^{* * *} \pm 0.04$ & $0.135^{* * *} \pm 0.07$ \\
& 300 & $0.160^{*} \pm 0.106$ & $0.098^{* * *} \pm 0.05$ & $0.080^{* * *} \pm 0.02$ & $0.096^{* * *} \pm 0.04$ & $0.098^{* * *} \pm 0.04$ \\
Diclofenac sodium & 10 & $0.130^{* * *} \pm 0.06$ & $0.101^{* * *} \pm 0.08$ & $0.070^{* * *} \pm 0.02$ & $0.081^{* * *} \pm 0.05$ & $0.096^{* * *} \pm 0.07$ \\
\hline
\end{tabular}

Values are reported as mean $\pm S E M, n=06$. Data was analyzed by ANOVA followed by post hoc Dunnett's test for multiple comparisons. Asterisks show significant values from control. ${ }^{*} P<0.05,{ }^{* *} P<0.01{ }^{* * *} P<0.001$

documented that the ethyl acetate fraction of the crude methanolic extract of this plant has shown significant antidiabetic effect in Alloxan induced diabetic rabbits, which endorse the folkloric use of the plant [12]. Islam et al, explored the antiulcerogenic and cytoprotective effects of the alcoholic extract of T. stocksianum [13]. Radhakrishnan et al [14] determined the anti-inflammatory effect of the ethanolic crude extract of the aerial part of T. stocksianum. But the detail mechanism of anti-inflammatory potential is not been reported elsewhere. In order to determine the possible anti-inflammatory mechanism, crude ethanolic extract and its subsequent fractions were initially screened for anti-inflammatory activity. Finally, the most potent fraction i.e. ethyl acetate was selected for the determination of possible anti-inflammatory mechanism using various inflammatory phlogistic agents in mice.

\section{Methods}

\section{Plant material}

T. stocksianum was collected in the month of May 2012 from District Swat in the province of Khyber Pakhtunkhwa (KPK), Pakistan and was identified by Professor Dr. Nasrullah, Department of Botany, University of Malakand, Pakistan. Voucher specimen was deposited in the Herbarium of the same Department having reference number H.UOM.BG.199. Plant was washed with tape water, shad dried and pulverized to coarse powder. About $2 \mathrm{~kg}$ of the plant material was extracted with ethanol (80\%), yielded $7.5 \%$ (150 g) crud extract. The ethanolic crud extract were suspended in distilled water and fractionation was carried out using successive solventsolvent extraction method. This resulted in $26 \mathrm{~g}$ (1.30\%), $38 \mathrm{~g}(1.90 \%), 47 \mathrm{~g}(2.35 \%)$ and $23 \mathrm{~g}(1.15 \%)$ of

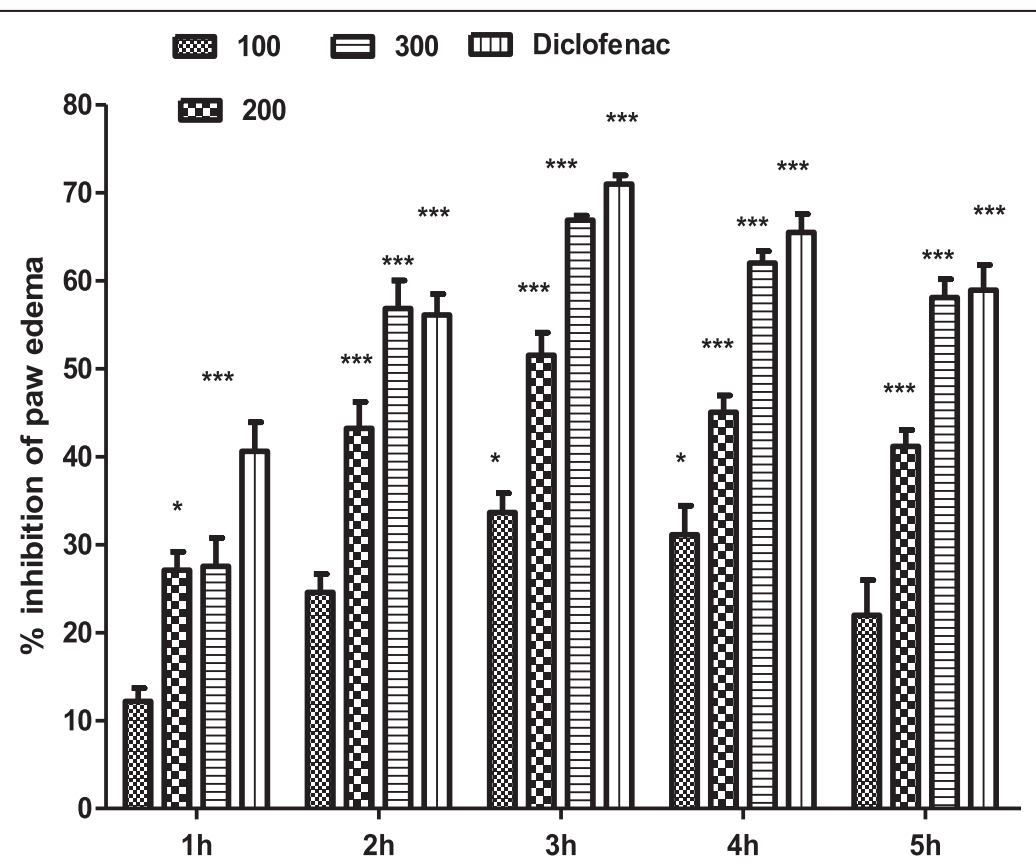

Fig. 1 Percent inhibition produced by ethyl acetate fraction (100, 200 and $300 \mathrm{mg} / \mathrm{kg})$ of $T$. stocksianum in carrageenan induced paw edema model in mice. Each percent point represents the mean \pm SEM for group of 06 mice. Data was analyzed by ANOVA followed by post hoc Dunnett's test. Asterisks show significant values from control. ${ }^{*} P<0.05,{ }^{* *} P<0.01,{ }^{* *} P<0.001$ 
$n$-hexane, chloroform, ethyl acetate and aqueous fraction respectively.

\section{Experimental animal}

In the present study Swiss albino mice of either sex (25-30 g) were used. Animals were procured from the Pharmacology section of National Institute of Health, Islamabad, Pakistan. Animals were maintained in suitable cages under controlled laboratory conditions of 23-25 ${ }^{\circ} \mathrm{C}$ with $12 \mathrm{~h}$ light/dark cycle and had a free access to food and water during acclimatization period. The experimental procedures were approved by the ethical committee of the Department of Pharmacy University of Malakand, KPK, Pakistan.

\section{Chemicals/drugs and solubility}

In this study we used Carrageenan, Histamine, Chlorpheniramine maleate, Bradykinin acetate, Arachedonic acid, Caffeic acid and Prostaglandin $E_{2}$ which were purchased from Sigma Chemicals Company, USA. While Acetylsalicylic acid used was of Reckit \& Colman, Pakistan (Aspirin).

Stock solution of Bradykinin was prepared with $70 \%$ ethanol and was further diluted with $0.1 \%$ ethanol. Arachedonic acid was dissolved in carbonate buffer $\left(\mathrm{Na}_{2} \mathrm{CO}_{3}, 0.2 \mathrm{M}, \mathrm{pH} 8.5\right)$. Caffeic acid solution was prepared in $10 \%$ dimethylsulphoxide (DMSO). The ethanolic extract and subsequent fractions of $T$. stocksianum were prepared as 100, 200 and $300 \mathrm{mg}$ in $10 \mathrm{ml}$ of $10 \%$ DMSO. Rests of the chemicals were dissolved in $0.9 \%$ normal saline solution.

\section{Anti-inflammatory activity of Teucrium stocksianum in mice}

The preliminary anti-inflammatory activity of $T$. stocksianum was evaluated on mice of either sex (25-30 g). Thirty (30) mice were divided randomly in five groups (Groups A-E) each group containing 06 mice [15]. Group A served as a negative control, received $10 \mathrm{ml} / \mathrm{kg}$ of $10 \%$ DMSO, group B was treated with Acetylsalicylic acid $100 \mathrm{mg} / \mathrm{kg}$ (positive control), while group C, D and E received 100, 200 and $300 \mathrm{mg} / \mathrm{kg}$, intraperitoneally, ethyl acetate fraction of $T$. stocksianum respectively. After $30 \mathrm{~min}$, freshly prepared saline suspension of

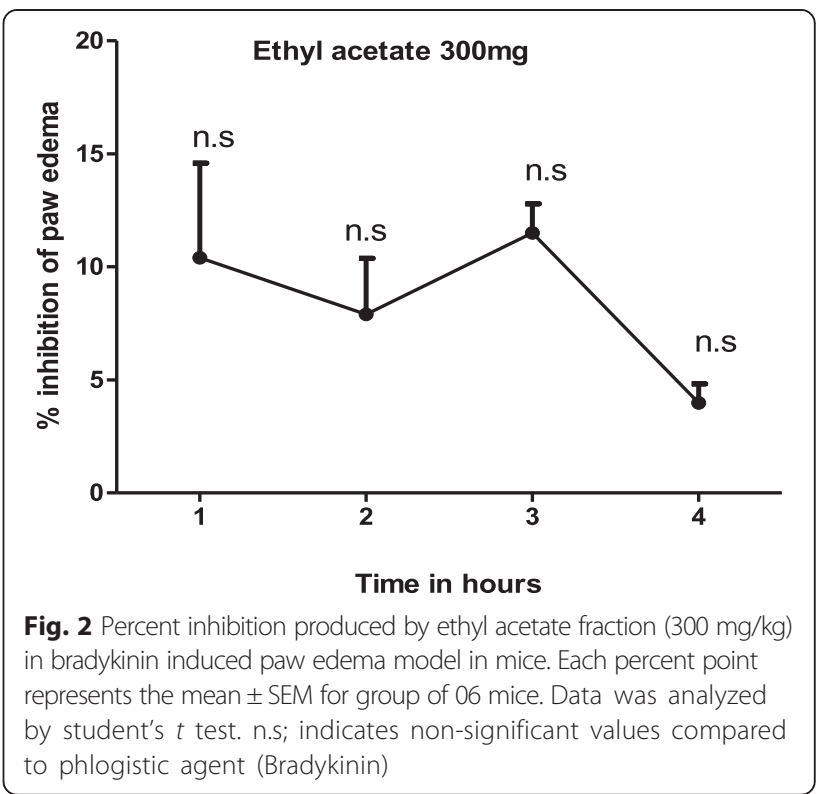

carrageenan $(0.05 \mathrm{ml}$ of $1 \% \mathrm{w} / \mathrm{v})$ was administered subcutaneously in the sub planter surface of the right hind paw of each mouse. The inflammation was immediately measured with plethysmometer (LE 7500 plan lab S.L) after injection of the irritant (carrageenan) at $1 \mathrm{~h}$ interval for $5 \mathrm{~h}$. Paw volume of the standard drug and drug treated animals were measured at different intervals and were compared with that of negative control group animals. Percent inhibition of inflammation was calculated using the following formula;

$$
\text { Percent inhibition }=\frac{\mathrm{C}-\mathrm{T}}{\mathrm{C} \times 100}
$$

Where $\mathrm{C}$ is the average inflammation of control and $\mathrm{T}$ is the paw volume of tested group [16].

\section{Mechanism of anti-inflammatory activity of Teucrium stocksianum in mice}

The experimental animals of either sex were randomly divided in to various groups. The animals received intraperitoneally injection of $10 \%$ DMSO or $0.9 \%$ saline or chlorpheniramine maleate $25 \mathrm{mg} / \mathrm{kg}$ (antihistaminic) or $100 \mathrm{mg} / \mathrm{kg}$ caffeic acid (lipoxygenase inhibitor) or aspirin

Table 2 Anti-inflammatory effect of ethyl acetate extract of T.stocksianum, in bradykinin and prostaglandin induced paw edema test

\begin{tabular}{llllll}
\hline Treatment & Dose & $1 \mathrm{~h}$ & $2 \mathrm{~h}$ & $3 \mathrm{~h}$ & $4 \mathrm{~h}$ \\
\hline Bradykinin & $20 \mu \mathrm{g} / \mathrm{ml}$ & $0.251 \pm 0.09$ & $0.220 \pm 0.0093$ & $0.198 \pm 0.0105$ & $0.210 \pm 0.01125$ \\
EAF & $300 \mathrm{mg} / \mathrm{kg}$ & $0.225^{\text {n.s }} \pm 0.012$ & $0.201^{\mathrm{n.s}} \pm 0.054$ & $0.175^{\text {n.s }} \pm 0.08$ & $0.201^{\mathrm{n} . \mathrm{s}} \pm 0.0109$ \\
PGE $_{2}$ & $0.01 \mathrm{mg} / \mathrm{ml}$ & $0.231 \pm 0.06$ & $0.240 \pm 0.057$ & $0.251 \pm 0.040$ & $0.260 \pm 0.0052$ \\
EAF & $300 \mathrm{mg} / \mathrm{kg}$ & $0.078^{* * *} \pm 0.065$ & $0.075^{* * *} \pm 0.043$ & $0.733^{* * *} \pm 0.04$ & $0.070^{* * *} \pm 0.036$ \\
\hline
\end{tabular}

EAF ethyl acetate fraction, $P G E_{2}$ prostaglandin $E_{2}$. Values are reported as mean $\pm S E M, n=06$. Data was analyzed by student's $t$ test. Asterisks show significant ${ }^{*} P<0.05,{ }^{* *} P<0.01,{ }^{* * *} P<0.001$ and $n . s$; indicates non-significant percent inhibition compared to respective Phlogistic agents 
Table 3 Anti-inflammatory effect of ethyl acetate extract (EAF) of T.stocksianum, in histamine induced paw edema test

\begin{tabular}{llllll}
\hline Test sample/drug & Dose & $1 \mathrm{~h}$ & $2 \mathrm{~h}$ & $3 \mathrm{~h}$ & $4 \mathrm{~h}$ \\
\hline Histamine & $1 \mathrm{mg} / \mathrm{ml}$ & $0.270 \pm 0.036$ & $0.248 \pm 0.06$ & $0.231 \pm 0.065$ & $0.230 \pm 0.081$ \\
CPM & $25 \mathrm{mg} / \mathrm{kg}$ & $0.0767^{* * *} \pm 0.055$ & $0.105^{* * *} \pm 0.062$ & $0.0783^{* * *} \pm 0.075$ & $0.183 \pm 0.088$ \\
EAF & $300 \mathrm{mg} / \mathrm{kg}$ & $0.221 \pm 0.08$ & $0.171^{* *} \pm 0.08$ & $0.185^{*} \pm 0.088$ & $0.218 \pm 0.060$ \\
\hline
\end{tabular}

$E A F$ ethyl acetate fraction. Values are reported as mean $\pm S E M, n=06$. Data was analyzed by ANOVA followed by post hoc Dunnett's test. Asterisks show significant values from phlogistic agent (Histamine). ${ }^{*} P<0.05$, ${ }^{* *} P<0.01,{ }^{* * *} P<0.001$

$100 \mathrm{mg} / \mathrm{kg}$ or $300 \mathrm{mg} / \mathrm{kg}$ ethyl acetate fraction of $T$. stocksianum. After $30 \mathrm{~min}$ of the above intraperitoneal administration, paw inflammation was induced in the right hind paw of mice by sub planter injection of $0.1 \mathrm{ml}$ of histamine $(1 \mathrm{mg} / \mathrm{ml})$ or arachedonic acid $(0.5 \% \mathrm{w} / \mathrm{v})$ or bradykinin $(20 \mu \mathrm{g} / \mathrm{ml})$ or prostaglandin E2 $(0.01 \mu \mathrm{g} / \mathrm{ml})$. Paw volume of each mouse was immediately measured before and after the sub planter administration of different irritants (inflammatory agents) at $1,2,3$ and $4 \mathrm{~h}$.

\section{Statistical analysis and calculations}

All the results obtained were articulated as mean \pm SEM of 06 animals. One-way analysis of variance (ANOVA) followed by post hoc Dunnett's test multiple comparison test was applied for the comparison among various groups and Student's $t$ test to determine the significance of differences between two means. Differences with $P \leq 0.05$ and lower between groups were considered significant.

Nearly all the edemogens produced the peek inflammatory response at the $3^{\text {rd }} \mathrm{h}$ on the hind paw of control animal, followed by decline in swelling at $4^{\text {th }} \mathrm{h}$. Moreover, the inflammatory response evoked by Histamine, Bradykinin, Prostaglandin $\mathrm{E}_{2}$, Arachedonic acid and Carrageenan, were

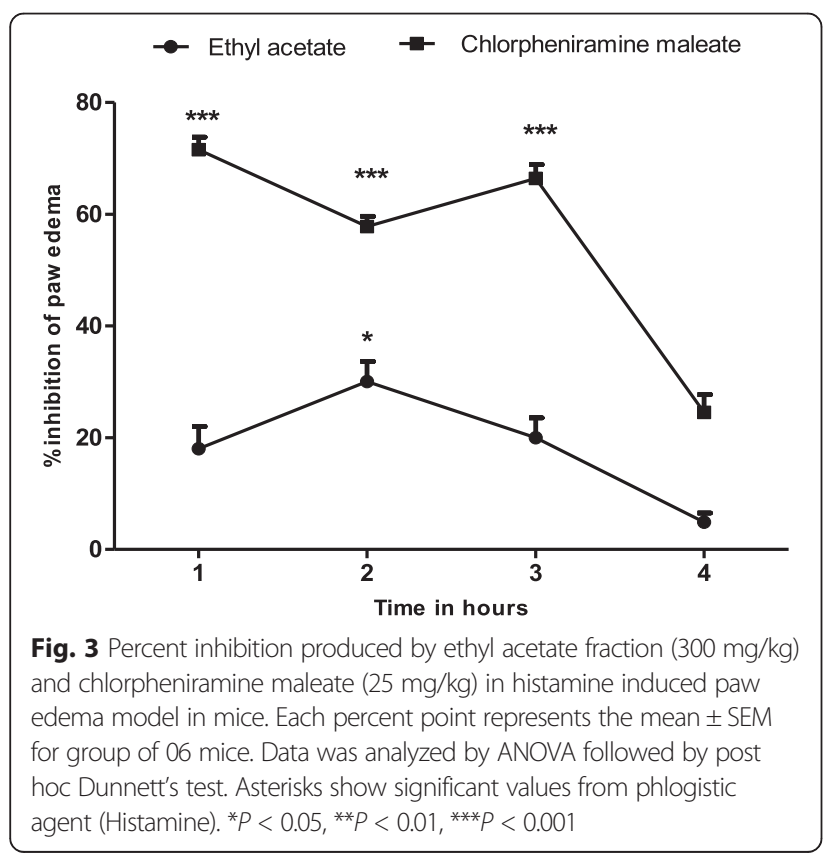

not significant in the presence of vehicles, $10 \%$ DMSO or normal saline in mice, consequently the observations were pooled $(n=30)$.

\section{Results and Discussion}

Preliminary anti-inflammatory activity of the crude ethanolic extract and subsequent fractions of T. stocksianum were determined in carrageenan induced paw edema in mice. All the test samples displayed a dose dependent and significant anti-inflammatory activity. The ethyl acetate fraction (EAF) at a dose of 100, 200 and $300 \mathrm{mg} / \mathrm{kg}$ exhibited highest anti-inflammatory potential (results of rest of the fractions are not presented). EAF demonstrated excellent (66 \%) anti-inflammatory action at the highest tested dose $(300 \mathrm{mg} / \mathrm{kg})$ that reached to the maximum value at $3^{\text {rd }}$ hour after carrageenan injection and remained significant $(* * * P<0.001)$ till $5^{\text {th }}$ hour of test sample administration, presented in Table 1. Aspirin has shown significant effect $\left(70.212 \%,{ }^{* * *} P<0.001\right)$ at a dose of $100 \mathrm{mg} / \mathrm{kg}$ at $3 \mathrm{~h}$ which is almost a similar effect to that produced by EAF at $300 \mathrm{mg} / \mathrm{kg}$ (Fig. 1).

Carrageenan induced inflammation is a well-established non-specific protocol for the determination of anti-

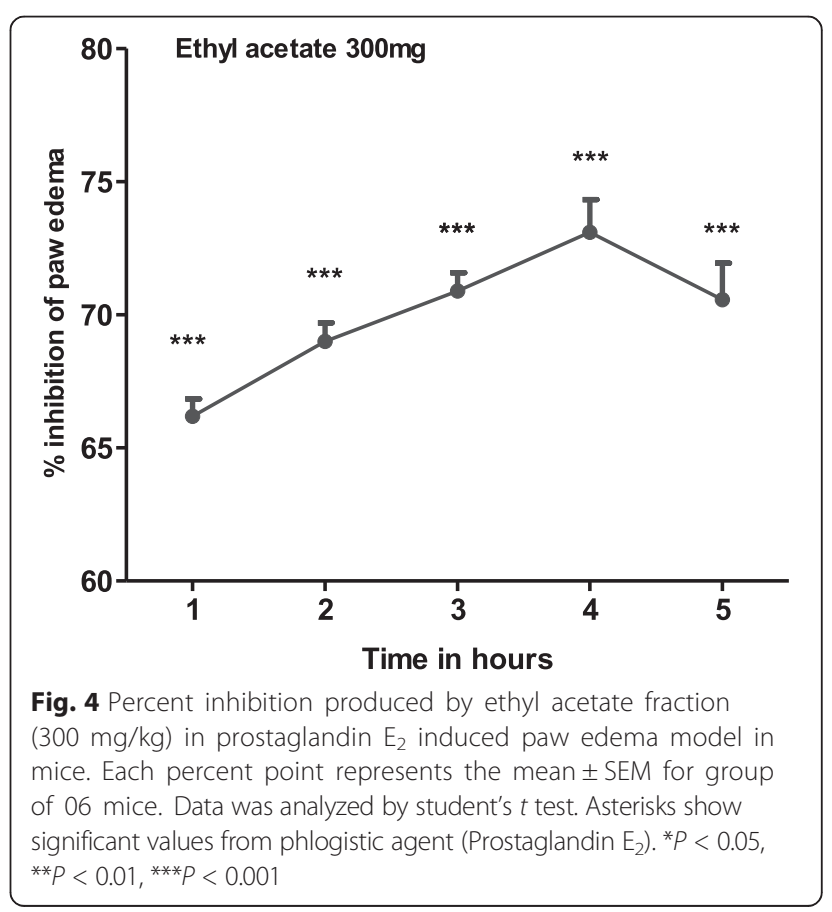




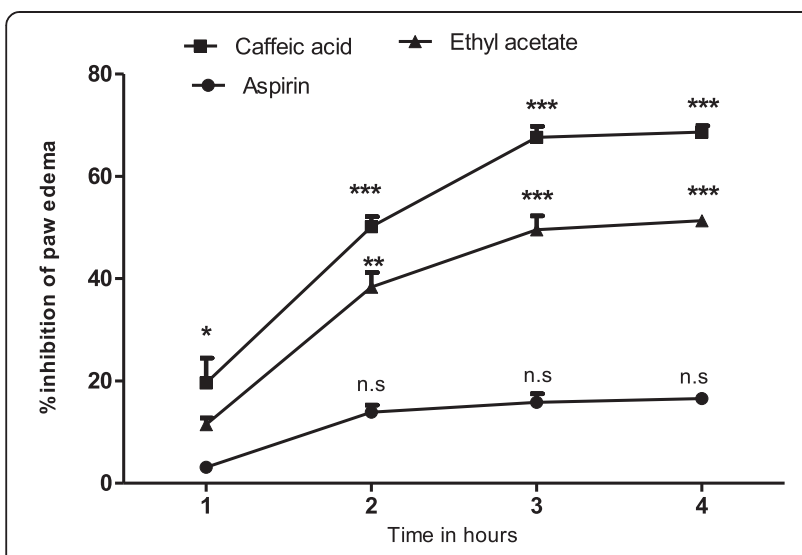

Fig. 5 Percent inhibition produced by aspirin (100 mg/kg), ethyl acetate fraction (300 mg/kg) and caffeic acid (100 mg/kg) in arachedonic acid induced paw edema model in mice. Each percent point represents the mean \pm SEM for group of 06 mice. Data was analyzed by ANOVA followed by post hoc Dunnett's test. Asterisks show significant ${ }^{*} P<0.05$, ${ }^{*} P<0.01,{ }^{* *} P<0.001$ and $n .5$; indicates non-significant values from phlogistic agent (Arachedonic acid)

inflammatory action of medicinal agents. Inflammation induced by carrageenan is believed to be biphasic. The first phase is mediated by the release of serotonin and histamine while the second phase is mediated by leukotrienes and prostaglandins produced by tissue macrophages and bradykinin which peek at $3 \mathrm{~h}$ [17]. To ascertain the possible mechanism of inhibition, anti-inflammatory activity of EAF ( $300 \mathrm{mg} / \mathrm{kg})$ was evaluated against various phlogistic agents including histamine, bradykinin, prostaglandin and arachedonic acid.

The ethyl acetate fraction could not antagonize the inflammation induced by bradykinin (Table 2, Fig. 2) but a mild antihistaminic effect (18.148-31.048 \%) was observed at $2 \mathrm{~h}$ of histamine administration, which may be due to the inhibitory effect of the extract on the release of mediators from mast cell (Table 3). Moreover, the reference standard drug chlorpheniramine maleate (antihistaminic) has significantly (65-72\%) decreased the edema induced by histamine (Fig. 3). Arachedonic acid is the main component of phospholipids of plasma membrane. Phospholipids are cleaved by an enzyme phospholipase $\mathrm{A}_{2}$, releases arachedonic acid which on oxidation (by cyclooxygenase) yields a strong pro-inflammatory mediator prostaglandin $\mathrm{PGE}_{2}$. Similarly, leukotrienes are produced as a result of arachedonic acid metabolism by lipoxygenase and could cause inflammation. This option convinced us to search out the most possible pathway of anti-inflammatory effect of $T$. stocksianum extract. In our study, we found that the plant extract significantly inhibited $(66.23-73.076 \%)$ the edematogenic effect in prostaglandin $\mathrm{E}_{2}\left(\mathrm{PGE}_{2}\right)$ induced paw edema (Fig. 4), signifying that the anti-inflammatory action of T. stocksianum extract is due to $\mathrm{PGE}_{2}$ inhibition. Same were the findings of Channa et al, who determined the anti-inflammatory activity of Bacopa monniera in rodents via prostaglandin inhibition [18]. Literature survey shows that the lipoxygenase shows significant anti-inflammatory action in carrageenan induced paw inflammation [19]. In order to determine the relative involvement of lipoxygenase pathway, edema was induced with arachedonic acid which is insensitive to cyclooxygenase inhibitors [20]. The plant extract and caffeic acid $(100 \mathrm{mg} / \mathrm{kg})$ both have significantly antagonized $(51.33 \%, 68.65 \%$ at $4 \mathrm{~h})$ the edematogenic effect of arachedonic acid respectively (Fig. 5), while aspirin remained unsuccessful in blocking the edema caused by arachedonic acid (Table 4). These findings suggest that the T. stocksianum extract possesses dual inhibitory property and has the potential to antagonize both cyclooxygenase and as well as lipoxygenase pathways of arachedonic acid metabolites, supported by the mild antihistaminic effect of the extract. Our results are in conformity with the findings of Sing et al, who reported the anti-inflammatory action in the oils extracted from Ocimum sanctum via dual inhibition of both pathways of arachedonic acid metabolites (cyclooxygenase and lipoxygenase) [21]. It is also well documented that calcium channel antagonists restrain the inflammation induced by various phlogistic agents like bradykinin, serotonin, prostaglandin and carrageenan [22]. Therefore, the anti-inflammatory action of T. stocksianum could be presumed through calcium channel blocking effect. Ali et al, have demonstrated the calcium channel blocking effect of the crude methanolic extract of T. stocksianum [23], which authenticated our assumption.

Table 4 Anti-inflammatory effect of ethyl acetate extract of T.stocksianum, in arachedonic acid induced paw edema test

\begin{tabular}{llllll}
\hline Test sample/drug & Dose & $1 \mathrm{~h}$ & $2 \mathrm{~h}$ & $3 \mathrm{~h}$ & $4 \mathrm{~h}$ \\
\hline Ard & $0.5 \% \mathrm{w} / \mathrm{v}$ & $0.2050 \pm 0.061$ & $0.2300 \pm 0.077$ & $0.2516 \pm 0.030$ & $0.2500 \pm 0.025$ \\
C.Acid & $100 \mathrm{mg} / \mathrm{kg}$ & $0.1666^{*} \pm 0.102$ & $0.1150^{* *} \pm 0.071$ & $0.0816^{* *} \pm 0.060$ & $0.0783^{* *} \pm 0.030$ \\
EAF & $300 \mathrm{mg} / \mathrm{kg}$ & $0.1816 \pm 0.074$ & $0.1416^{*} \pm 0.074$ & $0.1233^{* *} \pm 0.076$ & $0.1216^{* *} \pm 0.030$ \\
Aspirin & $100 \mathrm{mg} / \mathrm{kg}$ & $0.1983 \pm 0.047$ & $0.1983 \pm 0.087$ & $0.215 \pm 0.020$ & $0.235 \pm 0.042$ \\
\hline
\end{tabular}

Ard arachedonic acid, C.Acid caffeic acid, EAF ethyl acetate fraction. Values are reported as mean \pm SEM, $\mathrm{n}=06$. Data was analyzed by ANOVA followed by post hoc Dunnett's test. Asterisks show significant values from Phlogestic agent (Arachedonic acid). ${ }^{*} P<0.01,{ }^{* *} P<0.001$ 
Phytochemicals screening have confirmed the presence of flavonoids, saponins and terpenoids, all these classes of phytochemicals are responsible for multiple pharmacological actions including anti-inflammatory activity [24-26].

\section{Conclusion}

In conclusion, this research study revealed that the ethyl acetate fraction of $T$. stocksianum possesses significant anti-inflammatory activity via dual inhibition of both cyclooxygenase and lipoxygenase pathways of arachedonic acid metabolites. Moreover, highly significant effect was observed via prostaglandin inhibition. These results support the folkloric use of the plant in the treatment of various inflammatory conditions.

\section{Competing interests}

The author declares that he has no competing interests.

\section{Author's contributions}

SMMS performed the overall research work and manuscript drafting.

\section{Acknowledgments}

We are grateful to Pakistan Council of Science and Industrial Research (PCSIR), Peshawar, KPK, Pakistan for giving us access to Pharmacology laboratory and technical assistance on Plethysmometer (used for anti-inflammatory activity).

Received: 15 June 2015 Accepted: 26 August 2015

Published online: 29 August 2015

\section{References}

1. Shirwaikar A, Verma R, Lobo R, Shirwaikar A. Phytotherapy-safety aspects. Nat Prod Radiance. 2009;8(1):55-63.

2. Shah S, Shah SMM, Ahmad Z, Yaseen M, Shah R, Sadiq A, et al. Phytochemicals, in vitro antioxidant, total phenolic contents and phytotoxic activity of Cornus macrophylla Wall bark collected from the North-West of Pakistan. Pakistan J Pharm Sci. 2015;28(1):23-8.

3. Ali S, Nasir Y. 1991. Flora of Pakistan 1990:191-192.

4. Richardson P. The chemistry of the Labiatae: an introduction and overview. In: Advances in Labiate Science. United Kingdom: Royal Botanic Gardens, Kew; 1992. p. 291-7.

5. Zgórka G, Głowniak K. Variation of free phenolic acids in medicinal plants belonging to the Lamiaceae family. J Pharm Biomed Anal. 2001;26(1):79-87.

6. Ibrar M, Hussain F. Ethnobotanical studies of plants of Charkotli hills, Batkhela district, Malakand, Pakistan. Front Biol China. 2009:4(4):539-48.

7. Wazir SM, Saima S, Dasti AA, Subhan S. Ethanobotnical importance of salt range species of district karak, Pakistan. Pakistan J Plant Sci. 2007;13:29-31.

8. Shah SMM, Ullah F, Shah SMH, Zahoor M, Sadiq A. Analysis of chemical constituents and antinociceptive potential of essential oil of Teucrium Stocksianum bioss collected from the North West of Pakistan. BMC Complement Altern Med. 2012;12(1):244.

9. Shah SM, Sadiq A, Ullah F. Antioxidant, total phenolic contents and antinociceptive potential of Teucrium stocksianum methanolic extract in different animal models. BMC Complement Altern Med. 2014;14(1):181.

10. Shah SMM, Sadiq A. Biological activities of crude saponins, methanolic extract and sub fractions of Teucrium stocksianum Bioss collected from North West of Pakistan. Pharmacologyonline. 2014;3:145-52

11. Shah SMM, Sadiq A, Shah SMH, Khan S. Extraction of saponins and toxicological profile of Teucrium stocksianum boiss extracts collected from District Swat. Pakistan Biol Res. 2014;47(1):65

12. Rashid M, Bashir S, Mushtaq MN, Khan HU, Malik MNH, Qayyum A, et al. Comparative hypoglycemic activity of different extracts of Teucrium stocksianum in diabetic rabbits. Bangladesh J Pharmacol. 2013;8(2):186-93.

13. Islam M, Zakaria M, Radhakrishnan R, Kamil M. Effect of Teucrium stocksianum on gastric ulceration and secretion in rats. Pharm Biol. 2002;40(3):216-20.
14. Radhakrishnan R, Zakaria M, Islam M, Kamil M, Ismail A, Chan K, et al. Analgesic and anti-inflammatory activities of Teucrium stocksianum. Pharma Biol. 2001;39(6):455-9.

15. Muhammad N, Saeed M, Khan H. Antipyretic, analgesic and anti-inflammatory activity of Viola betonicifolia whole plant. BMC Complement Alterna Med. 2012;12(1):59.

16. Adedapo AA, Sofidiya MO, Maphosa V, Moyo B, Masika PJ, Afolayan AJ. Anti-inflammatory and analgesic activities of the aqueous extract of Cussonia paniculata stem Bark. J Nat Prod Res. 2008;2(2):46-53.

17. Musa A, Aliyu A, Yaro A, Magaji M, Hassan H, Abdullahi M. Preliminary phytochemical, analgesic and anti-inflammatory studies of the methanol extract of Anisopus mannii (NE Br)(Asclepiadaceae) in rodents. Afric J Pharm Pharmacol. 2009;3(8):374-8.

18. Channa S, Dar A, Anjum S, Yaqoob M. Anti-inflammatory activity of Bacopa monniera in rodents. J Ethnopharmacol. 2006;104(1):286-9.

19. Chawla A, Singh M, Murthy M, Gupta M, Singh H. Anti-inflammatory action of ferulic acid and its esters in carrageenan induced rat paw oedema model. Indian J Exp Biol. 1987;25(3):187-9.

20. DiMartino M, Campbell Jr G, Wolff C, Hanna N. The pharmacology of arachidonic acid-induced rat paw edema. Agents Actions. 1987:21(3-4):303-5.

21. Singh S, Majumdar D. Evaluation of antiinflammatory activity of fatty acids of Ocimum sanctum fixed oil. Indian J Exp Biology. 1997;35(4):380-3.

22. Sanchez S, Bartrons R, Rodriguez L, Gonzalez P, Planas ME, Lia A. Protective effect of nifedipine against carrageenan-induced inflammation. Pharmacol. 1998;56(3):131-6.

23. Ali N, Ali SS. Antispasmodic activity of Teucrium stocksianum Boiss. Pakistan J Pharm Sci. 2011;24(2):171-4

24. Kim HP, Son KH, Chang HW, Kang SS. Anti-inflammatory plant flavonoids and cellular action mechanisms. J Pharmacol Sci. 2004;96(3):229-45.

25. Salminen A, Lehtonen M, Suuronen T, Kaarniranta K, Huuskonen J. Terpenoids: natural inhibitors of NF-KB signaling with anti-inflammatory and anticancer potential. Cell Mol Life Sci. 2008;65(19):2979-99.

26. Sur P, Chaudhuri T, Vedasiromoni J, Gomes A, Ganguly D. Antiinflammatory and antioxidant property of saponins of tea [Camellia sinensis $(\mathrm{L}) \mathrm{O}$. Kuntze] root extract. Phytothe Res. 2001;15(2):174-6.

\section{Submit your next manuscript to BioMed Central and take full advantage of:}

- Convenient online submission

- Thorough peer review

- No space constraints or color figure charges

- Immediate publication on acceptance

- Inclusion in PubMed, CAS, Scopus and Google Scholar

- Research which is freely available for redistribution 